\title{
FEATURE Advancing understanding of conservation practices on rented land
}

Peggy Petrzelka, Matthew J. Barnett, Gabrielle Roesch-McNally, and Jennifer Filipiak

$\mathbf{N}$ early $40 \%$ of farmland in the United States is rented or leased from agricultural landowners (USDA NASS 2015), the majority of whom are nonoperator landowners (NOLs). NOLs are increasingly identified as a group of landowners who should be included when discussing environmental issues on agricultural lands. Yet, who NOLs are and what we know about them in terms of conservation practices is limited. Comprehensive, national-scale data on NOLs in the United States have been provided only three times in history, coming from the Agricultural Economic Land Ownership Surveys (AELOS) that collected information from both landowners and renters in 1988 and 1999 as follow-ups to the periodic Census of Agriculture (in 1987 and 1997, respectively) and the 2014 Tenure, Ownership, and Transition of Agricultural Land Survey (TOTAL) survey. While these surveys contribute to our understanding of NOLs, there are many things we still do not yet know, particularly related to NOL conservation values, practices, and informational needs. In addition, most of the existing research on NOLs is from studies conducted in the Midwest (Ulrich-Schad et al. 2016). While the study findings have provided policymakers and practitioners with a sense of what NOLs in the Midwest look like, what NOLs look like in other geographical regions is yet to be explored but essential for getting more conservation practices implemented on rented agricultural lands.

Given how much land is rented in the United States, it has been clear to conservation practitioners for some time that a better understanding of NOLs beyond what the TOTAL survey provides is needed. For example, at a 2017 Land for Good conference, "Changing Land, Changing Hands," one point of agreement among those in attendance was that regional characteristics and needs of these agricultural landowners are distinct and require customized solutions (Land for Good 2017). A 2019 meeting put on by Green Lands Blue

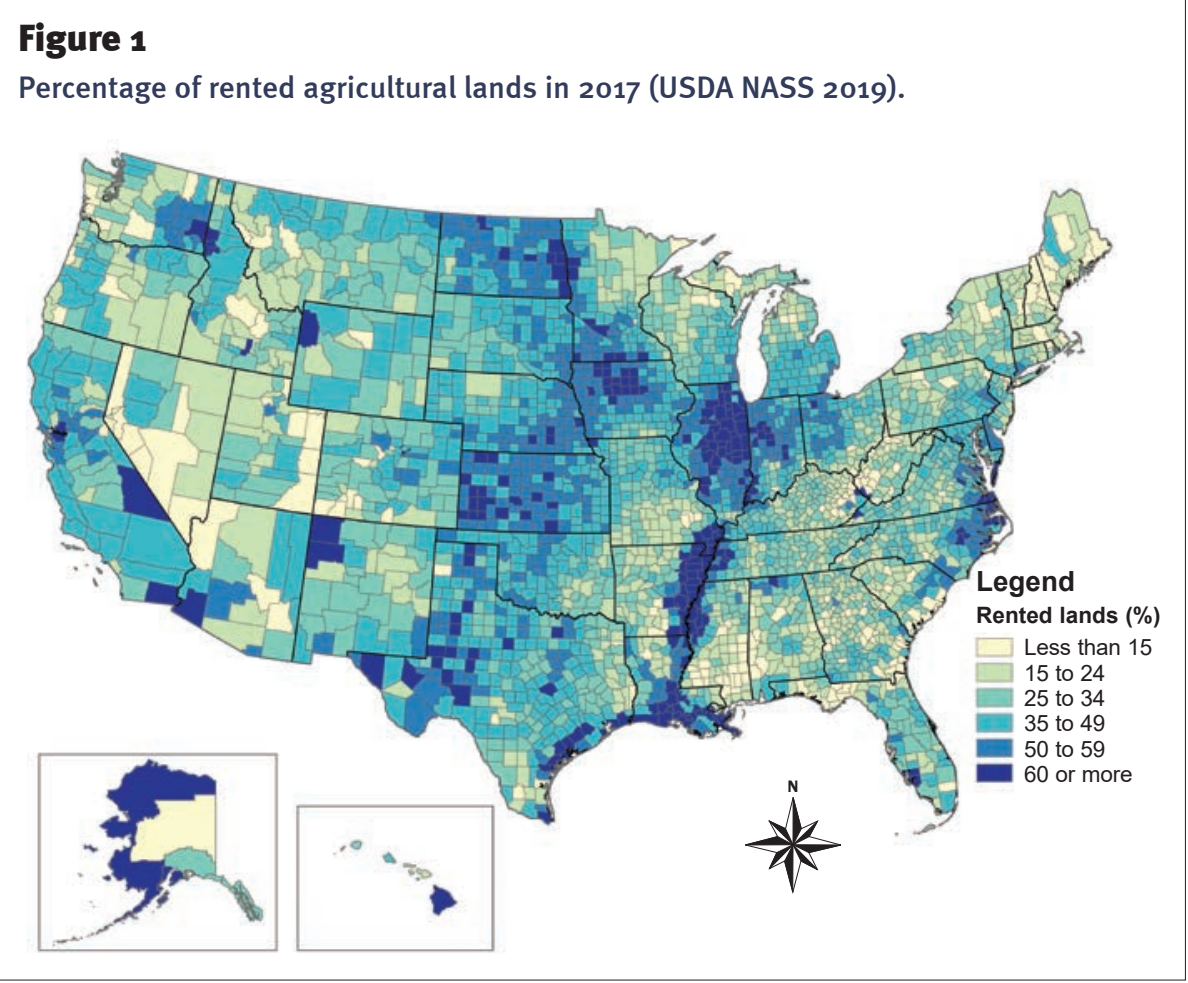

Waters brought practitioners and researchers together to discuss NOLs (Green Lands Blue Waters 2019), and a dominant need identified by the practitioners was a better understanding of NOLs in terms of who they are, and conservation interests and practices. Additionally, American Farmland Trust's (AFT's) work with NOLs and their renters to achieve more conservation and farmland preservation outcomes on rented lands has made clear that more information about NOLs is critical. Thus, AFT undertook a multistate survey of NOLs who rent some or all of their land to a farm operator, providing the most comprehensive data set to date on NOLs since the 2014 TOTAL survey. Surveying 13 states between 2018 and 2020 , the primary focus was on states with the largest amount of rented lands (figure 1), but also states that encompass a variety of USDA production regions. The 13 states include Arkansas, California, Illinois, Indiana, Iowa, Kansas, New York, North Carolina, Ohio, Pennsylvania, Texas, Virginia, and Washington.
Nonoperator landowner lists were purchased from Farm Market ID, which has "Owner" lists that do not include anyone who is an "Operator." The sampling intentionally focused on ensuring a 50/50 gender split, given that female landowners are underrepresented in surveys of agricultural landowners (Petrzelka et al. 2018) and make up to nearly $40 \%$ of the NOLS population themselves (USDA NASS 2015). More detail on the survey and survey methods can be found at http:// farmland.org/nolssurvey.

The $n$ for the overall sample is 3,958 , with a response rate ranging from $40 \%$ in Iowa to $6 \%$ in Virginia. (We recognize this latter response rate, and others, is quite low, and believe part of it was

Peggy Petrzelka is a professor of sociology at Utah State University, Logan, Utah. Matthew J. Barnett is a PhD student at Utah State University, Logan, Utah. Gabrielle Roesch-McNally is the Women for the Land director, American Farmland Trust, Washington, DC. Jennifer Filipiak is executive director of the Driftless Area Land Conservancy, Dodgeville, Wisconsin.

Received February 9, 2021. 
due to the COVID-19 pandemic occurring at the same time some surveys were being distributed). Given there is no study population of NOLs, we cannot say with certainty how representative our sample is to the actual population of NOLs, though several of the demographics as well as land and lease characteristics are comparable to those in the TOTAL survey, as we note throughout this article.

\section{WHO ARE NONOPERATOR LANDOWNERS?}

The landowners who responded were, on average, older, consistent with the TOTAL findings (Bigelow et al. 2016) (table 1). While near gender parity was obtained in some states and expected, given how we sampled (as discussed previously), the sample still skewed heavily toward males in other states. Regarding past farming experience among respondents, there is a large amount of between-state variation, but close to one-third of the sample in each state has had direct farming experience, comparable to the $38 \%$ of NOLs in the TOTAL survey who indicated they are retired farmers (Bigelow et al. 2016.)

There is a large amount of betweenstate variation when it comes to land area owned and rented, expected given the variation in acreage sizes between states in total farmland overall. Respondents tended to not live on the land they rent. Indeed, only three states, Indiana, New York, and Pennsylvania, had 50\% or more of the landowners living on their land. In contrast, only $17 \%$ of respondents in Arkansas and 16\% in Texas reported living on their land. For those who reported living off their land, the median distance they live from their land ranged from $3 \mathrm{mi}$ $(5 \mathrm{~km})$ for New York respondents to 152 mi $(245 \mathrm{~km})$ for Washington respondents.

How the land was acquired also varied greatly between the states. Those who owned land in New York and Pennsylvania acquired the land primarily by purchasing it, while landowners owning land in all other states primarily acquired the land by inheriting it. This latter group of landowners is comparable to the TOTAL data, where over $50 \%$ of NOLs acquired their land through inheritance (Bigelow et

\section{Table 1}

Nonoperator landowner demographics.

\begin{tabular}{|c|c|c|c|c|c|c|c|c|c|c|c|c|c|}
\hline Selected characteristics/land specifics & AR & CA & IA & IL & IN & KS & NY & NC & $\mathbf{O H}$ & PA & TX & VA & WA \\
\hline Age (average) & 68 & 70 & 73 & 69 & 71 & 69 & 65 & 72 & 70 & 66 & 70 & 71 & 69 \\
\hline Male & $59 \%$ & $57 \%$ & $51 \%$ & $55 \%$ & $57 \%$ & $53 \%$ & $72 \%$ & $58 \%$ & $51 \%$ & $68 \%$ & $53 \%$ & $62 \%$ & $49 \%$ \\
\hline Female & $41 \%$ & $43 \%$ & $49 \%$ & $45 \%$ & $43 \%$ & $47 \%$ & $28 \%$ & $42 \%$ & $49 \%$ & $32 \%$ & $47 \%$ & $38 \%$ & $51 \%$ \\
\hline \multicolumn{14}{|l|}{ Education levels } \\
\hline High school graduate (or equivalent) & $15 \%$ & $8 \%$ & $35 \%$ & $22 \%$ & $37 \%$ & $12 \%$ & $20 \%$ & $17 \%$ & $28 \%$ & $27 \%$ & $12 \%$ & $19 \%$ & $8 \%$ \\
\hline Some college, no degree & $21 \%$ & $22 \%$ & $17 \%$ & $19 \%$ & $16 \%$ & $19 \%$ & $13 \%$ & $17 \%$ & $16 \%$ & $12 \%$ & $17 \%$ & $21 \%$ & $18 \%$ \\
\hline Bachelor's degree & $27 \%$ & $36 \%$ & $20 \%$ & $27 \%$ & $13 \%$ & $30 \%$ & $24 \%$ & $24 \%$ & $18 \%$ & $24 \%$ & $33 \%$ & $22 \%$ & $32 \%$ \\
\hline Graduate or professional degree & $27 \%$ & $26 \%$ & $12 \%$ & $19 \%$ & $25 \%$ & $28 \%$ & $21 \%$ & $24 \%$ & $24 \%$ & $22 \%$ & $33 \%$ & $26 \%$ & $32 \%$ \\
\hline \multicolumn{14}{|l|}{ Net farm income (pre-tax, 2017)* } \\
\hline$<\$ 25,000$ & $51 \%$ & $26 \%$ & $38 \%$ & $59 \%$ & $67 \%$ & $65 \%$ & $57 \%$ & $77 \%$ & $61 \%$ & $66 \%$ & $67 \%$ & $81 \%$ & $54 \%$ \\
\hline$\$ 25,001$ to $\$ 75,000$ & $29 \%$ & $31 \%$ & $42 \%$ & $30 \%$ & $23 \%$ & $26 \%$ & $27 \%$ & $14 \%$ & $27 \%$ & $23 \%$ & $16 \%$ & $12 \%$ & $32 \%$ \\
\hline$\$ 75,001$ to $\$ 125,000$ & $7 \%$ & $16 \%$ & $14 \%$ & $5 \%$ & $6 \%$ & $6 \%$ & $8 \%$ & $4 \%$ & $6 \%$ & $6 \%$ & $9 \%$ & $5 \%$ & $8 \%$ \\
\hline$\$ 125,001$ or more & $13 \%$ & $27 \%$ & $7 \%$ & $7 \%$ & $4 \%$ & $3 \%$ & $8 \%$ & $5 \%$ & $6 \%$ & $5 \%$ & $9 \%$ & $3 \%$ & $7 \%$ \\
\hline \multicolumn{14}{|l|}{ Experience with farming } \\
\hline Have operated a farm & $39 \%$ & $59 \%$ & $56 \%$ & $32 \%$ & $40 \%$ & $31 \%$ & $71 \%$ & $33 \%$ & $41 \%$ & $54 \%$ & $38 \%$ & $47 \%$ & $33 \%$ \\
\hline Have helped our parents farm & $21 \%$ & $15 \%$ & $24 \%$ & $31 \%$ & $33 \%$ & $34 \%$ & $16 \%$ & $44 \%$ & $28 \%$ & $25 \%$ & $26 \%$ & $23 \%$ & $31 \%$ \\
\hline No experience & $34 \%$ & $22 \%$ & $10 \%$ & $27 \%$ & $18 \%$ & $26 \%$ & $7 \%$ & $17 \%$ & $23 \%$ & $14 \%$ & $34 \%$ & $22 \%$ & $29 \%$ \\
\hline Farmland owned (ac, median) & 213 & 290 & 171 & 120 & 100 & 237 & 190 & 60 & 100 & 108 & 250 & 140 & 406 \\
\hline Farmland rented out (ac, median) & 190 & 199 & 150 & 90 & 70 & 173 & 83 & 40 & 80 & 70 & 200 & 81 & 320 \\
\hline Live on parcel of land & $17 \%$ & $31 \%$ & $43 \%$ & $28 \%$ & $50 \%$ & $18 \%$ & $66 \%$ & $35 \%$ & $46 \%$ & $69 \%$ & $16 \%$ & $47 \%$ & $20 \%$ \\
\hline $\begin{array}{l}\text { Distance live from land if nonresident } \\
\text { (mi, median) }\end{array}$ & 45 & 30 & 15 & 22 & 10 & 143 & 3 & 38 & 15 & 9 & 145 & 40 & 152 \\
\hline \multicolumn{14}{|l|}{ How acquired land $\dagger$} \\
\hline Purchased & $36 \%$ & $47 \%$ & $63 \%$ & $46 \%$ & $55 \%$ & $39 \%$ & $73 \%$ & $30 \%$ & $54 \%$ & $71 \%$ & $28 \%$ & $41 \%$ & $34 \%$ \\
\hline Inherited & $72 \%$ & $64 \%$ & $51 \%$ & $67 \%$ & $56 \%$ & $72 \%$ & $33 \%$ & $84 \%$ & $57 \%$ & $39 \%$ & $81 \%$ & $72 \%$ & $75 \%$ \\
\hline Sole owner & $43 \%$ & $56 \%$ & $66 \%$ & $59 \%$ & $65 \%$ & $54 \%$ & $67 \%$ & $57 \%$ & $63 \%$ & $63 \%$ & $51 \%$ & $53 \%$ & $58 \%$ \\
\hline
\end{tabular}

Notes: This table highlights primary responses only; therefore, percentages do not necessarily add up to $100 \%$. States are identified by postal codes.

* PA and VA respondents' answers provided on pre-tax 2019.

† Could select multiple categories. 
al. 2016). Respondents tended to be sole owners of the land, with at least $50 \%$ indicating sole ownership in all states except for Arkansas.

Involvement in Conservation. Involvement in government conservation programs varied widely across the states, in part to be expected given the varying types of programs that are appropriate for each state (table 2). For example, there was high use of land-set-aside programs such as the Conservation Reserve Program or Wetland Reserve Program by landowners who owned land in Iowa and Pennsylvania, but there was low use in North Carolina. Land-set-aside programs received the highest percentage of respondents indicating their use in all states other than California, New York, and North Carolina. For these three states, the highest level of participation was in receiving conservation practices/technical assistance from USDA Natural Resource Conservation Service (NRCS) or the soil and water conservation district (SWCD). Across the board, however, our results suggest that many of the NOLs surveyed had less awareness about government conservation programs and very little use of local NRCS or SWCD staff or technical assistance. This lack of knowledge about, and engagement with, programs that could support greater conservation is a real barrier to achieving conservation practice adoption on rented lands.
Nonoperator Landowners' Relationships with their Renters. Because the relationship between the landowner and renter is so critical to implementing conservation practices on the land, it was important to gain information on this relationship. The majority of landowners in our survey rented to people they know well, either a friend of the family or a family member (table 3). (The TOTAL data found that one-third of rented acres in 2014 were between related landlords and renters [Bigelow et al. 2016]). Verbal lease agreements were most common in the majority of states, while written agreements were most common in California, Iowa, New York, and Washington. A mix of a cash rent fixed or flex payment lease or crop share agreements were used, different from TOTAL, where the vast majority of leases were cash rent. The majority of leases were renewed annually, as they were in the TOTAL data, and the length of the relationship the landowner had with the renter was several years, ranging from a median of 8 years in New York to 17 years in Ohio, also similar to what was found by the TOTAL survey (Bigelow et al. 2016).

In all states, a very high percentage of respondents indicated that they trust their operator and are committed to their operator's continuation as a renter of their land. Additionally, respondents indicated that they are comfortable extending the length of their operator's lease to facilitate implementation of conservation practices on their land, that they are comfortable asking their operator to use certain conservation practices on their land, and that they are comfortable asking their operator to amend or make an addendum to their lease requiring conservation practices. Indeed, for all these statements at least $50 \%$ or more of respondents who held land in each state indicated agreement. In addition, $50 \%$ or more of respondents in Iowa, Illinois, Indiana, Kansas, New York, Ohio, Pennsylvania, and Virginia indicated that they would be willing to include lease provisions related to specific conservation practices (e.g., grassed waterways, notill, adaptive nutrient management, cover crops, filter strips, and wildlife habitat). Additionally, $50 \%$ or more of respondents in Iowa, Illinois, Kansas, New York, Pennsylvania, Texas, and Virginia indicated that they would be willing to include a lease provision that requires their operator to implement practices to conserve/ improve soil health.

Nonoperator Landowners' Information Sources and Needs. Given information is an essential component to conservation, we examined both the information sources used, and the information needs NOLs identified. From a list of 16 information sources, there is much commonality, with those owning land in all states (except New York) indicating that they rely on their farm operator/lessee first and foremost for information (table 4). Other top

\section{Table 2}

Nonoperator landowner involvement in conservation.

\begin{tabular}{|c|c|c|c|c|c|c|c|c|c|c|c|c|c|}
\hline Involvement type & AR & $\mathbf{C A}$ & IA & IL & IN & KS & NY & NC & $\mathrm{OH}$ & PA & TX & VA & WA \\
\hline $\begin{array}{l}\text { Land set aside programs, like } \\
\text { Conservation Reserve Program (CRP) or } \\
\text { Wetland Reserve Program (WRP) }\end{array}$ & $27 \%$ & $12 \%$ & $59 \%$ & $40 \%$ & $25 \%$ & $30 \%$ & $29 \%$ & $9 \%$ & $39 \%$ & $57 \%$ & $19 \%$ & $34 \%$ & $44 \%$ \\
\hline $\begin{array}{l}\text { Cost share programs, like } \\
\text { Environmental Quality Incentive Program } \\
\text { (EQIP) or Conservation Stewardship Program, } \\
\text { (CSP) that pay some costs of implementing } \\
\text { conservation practices }\end{array}$ & $22 \%$ & $15 \%$ & $29 \%$ & $12 \%$ & $12 \%$ & $18 \%$ & $21 \%$ & $6 \%$ & $15 \%$ & $19 \%$ & $14 \%$ & $27 \%$ & $20 \%$ \\
\hline $\begin{array}{l}\text { Received conservation practice technical } \\
\text { assistance from Natural Resource } \\
\text { Conservation Service or soil and } \\
\text { water conservation district staff }\end{array}$ & $22 \%$ & $17 \%$ & $35 \%$ & $20 \%$ & $20 \%$ & $19 \%$ & $34 \%$ & $13 \%$ & $34 \%$ & $41 \%$ & $16 \%$ & $32 \%$ & $15 \%$ \\
\hline
\end{tabular}

Note: States are identified by postal codes. 


\section{Table 3}

Nonoperator landowner relationship with renter.

\begin{tabular}{|c|c|c|c|c|c|c|c|c|c|c|c|c|c|}
\hline Relationship/lease characteristic & AR & CA & IA & IL & IN & KS & NY & NC & $\mathbf{O H}$ & PA & TX & VA & WA \\
\hline \multicolumn{14}{|l|}{ Best description of renter } \\
\hline Neighbor, friend of family & $38 \%$ & $37 \%$ & $39 \%$ & $44 \%$ & $50 \%$ & $32 \%$ & $55 \%$ & $53 \%$ & $49 \%$ & $51 \%$ & $38 \%$ & $48 \%$ & $35 \%$ \\
\hline Relative, family member & $20 \%$ & $18 \%$ & $41 \%$ & $34 \%$ & $20 \%$ & $42 \%$ & $18 \%$ & $14 \%$ & $31 \%$ & $19 \%$ & $19 \%$ & $21 \%$ & $40 \%$ \\
\hline Neither a relative nor friend of family & $41 \%$ & $42 \%$ & $20 \%$ & $22 \%$ & $29 \%$ & $26 \%$ & $28 \%$ & $32 \%$ & $20 \%$ & $30 \%$ & $43 \%$ & $31 \%$ & $24 \%$ \\
\hline \multicolumn{14}{|l|}{ Lease characteristics } \\
\hline Verbal & $56 \%$ & $14 \%$ & $47 \%$ & $63 \%$ & $68 \%$ & $71 \%$ & $46 \%$ & $70 \%$ & $62 \%$ & $64 \%$ & $55 \%$ & $64 \%$ & $33 \%$ \\
\hline Written & $43 \%$ & $85 \%$ & $52 \%$ & $37 \%$ & $31 \%$ & $29 \%$ & $54 \%$ & $29 \%$ & $38 \%$ & $36 \%$ & $44 \%$ & $34 \%$ & $66 \%$ \\
\hline Crop share agreement & $72 \%$ & $42 \%$ & $24 \%$ & $62 \%$ & $49 \%$ & $65 \%$ & $6 \%$ & $6 \%$ & $46 \%$ & $2 \%$ & $63 \%$ & $10 \%$ & $76 \%$ \\
\hline $\begin{array}{l}\text { Cash rent agreement with fixed or } \\
\text { flexible payment }\end{array}$ & $17 \%$ & $44 \%$ & $71 \%$ & $33 \%$ & $46 \%$ & $19 \%$ & $79 \%$ & $87 \%$ & $46 \%$ & $89 \%$ & $26 \%$ & $79 \%$ & $15 \%$ \\
\hline Annual term & $67 \%$ & $39 \%$ & $84 \%$ & $71 \%$ & $72 \%$ & $63 \%$ & $56 \%$ & $87 \%$ & $73 \%$ & $51 \%$ & $68 \%$ & $45 \%$ & $29 \%$ \\
\hline $\begin{array}{l}\text { Length of time have rented to } \\
\text { operator (median years) }\end{array}$ & 10 & 12 & 12 & 15 & 15 & 15 & 8 & 12 & 17 & 10 & 13 & 10 & 15 \\
\hline $\begin{array}{l}\text { Trust operator to make good } \\
\text { conservation decisions }\end{array}$ & $89 \%$ & $87 \%$ & $94 \%$ & $91 \%$ & $92 \%$ & $92 \%$ & $88 \%$ & $90 \%$ & $93 \%$ & $95 \%$ & $91 \%$ & $89 \%$ & $93 \%$ \\
\hline $\begin{array}{l}\text { Committed to operator's continuation } \\
\text { as renter }\end{array}$ & $88 \%$ & $83 \%$ & $87 \%$ & $88 \%$ & $88 \%$ & $88 \%$ & $76 \%$ & $87 \%$ & $88 \%$ & $85 \%$ & $87 \%$ & $86 \%$ & $89 \%$ \\
\hline $\begin{array}{l}\text { Comfortable extending length of operator's } \\
\text { lease to facilitate implementation of } \\
\text { conservation practices on land }\end{array}$ & $79 \%$ & $68 \%$ & $81 \%$ & $81 \%$ & $81 \%$ & $85 \%$ & $79 \%$ & $79 \%$ & $82 \%$ & $86 \%$ & $78 \%$ & $86 \%$ & $81 \%$ \\
\hline $\begin{array}{l}\text { Comfortable asking operator to use } \\
\text { certain conservation practices on land }\end{array}$ & $74 \%$ & $66 \%$ & $84 \%$ & $81 \%$ & $76 \%$ & $73 \%$ & $84 \%$ & $73 \%$ & $78 \%$ & $84 \%$ & $68 \%$ & $83 \%$ & $74 \%$ \\
\hline $\begin{array}{l}\text { Comfortable asking operator to amend/ } \\
\text { make addendum to lease requiring } \\
\text { conservation practices }\end{array}$ & $60 \%$ & $51 \%$ & $73 \%$ & $66 \%$ & $58 \%$ & $65 \%$ & $71 \%$ & $61 \%$ & $69 \%$ & $79 \%$ & $54 \%$ & $75 \%$ & $57 \%$ \\
\hline $\begin{array}{l}\text { Willing to include lease provisions relating } \\
\text { to specific conservation practices (e.g., } \\
\text { grassed waterways, no-till, adaptive } \\
\text { nutrient management, cover crops, filter } \\
\text { strips and wildlife habitat) }\end{array}$ & $38 \%$ & $33 \%$ & $61 \%$ & $54 \%$ & $50 \%$ & $50 \%$ & $51 \%$ & $44 \%$ & $52 \%$ & $68 \%$ & $42 \%$ & $54 \%$ & $41 \%$ \\
\hline $\begin{array}{l}\text { Willing to include lease provision that } \\
\text { requires operator to implement soil erosion } \\
\text { practices to conserve/improve soil health }\end{array}$ & $45 \%$ & $42 \%$ & $56 \%$ & $54 \%$ & $45 \%$ & $50 \%$ & $59 \%$ & $46 \%$ & $47 \%$ & $68 \%$ & $52 \%$ & $57 \%$ & $45 \%$ \\
\hline
\end{tabular}

Note: States are identified by postal codes.

information sources included SWCDs, NRCS, and state university extension.

Top preferences for information topics vary by state. For example, respondents owning land in North Carolina and Virginia were most interested in receiving information and/or technical assistance for soil erosion control. Respondents owning land in California, Iowa, New York, Ohio, and Pennsylvania were most interested in receiving information and/ or technical assistance for water quality improvement. Respondents in Illinois and Virginia were equally interested in soil erosion control and soil fertility improvement. Respondents in North Carolina were equally interested in soil fertility improvement and water quality improvement. These findings suggest there is an opportunity to cultivate awareness among NOLs who value soil quality, water quality, and other conservation efforts that could benefit their land.

\section{DISCUSSION OF NONOPERATOR LANDOWNER SURVEY FINDINGS}

The data and findings presented here begin to fill important data gaps and allow us to begin delineating NOLs by state and agricultural production regions, a valuable contribution to the NOL discussion. In addition, the findings also challenge some commonly made assumptions regarding NOLs, including (1) they care only about the bottom (financial) line, and (2) that they do not care about the land. When discussion of conservation on rented lands occurs, rented lands (and by extension, those renting their land) are often identified as the problem for why conservation is not occurring. For example, in the 2017 Land for Good conference, a top USDA Farm Service Agency official participating in a panel discussion about NOLs stated they "do not care about the land." The research on conservation on rented land also tends to focus on the farmer (i.e., the renter's) point of view, with suggestions 


\section{Table 4}

Nonoperator landowner conservation information sources and topics.

\begin{tabular}{|c|c|c|c|c|c|c|c|c|c|c|c|c|c|}
\hline Source/topic & AR & $\mathbf{C A}$ & IA & IL & IN & KS & NY & NC & OH & PA & $\mathbf{T X}$ & VA & WA \\
\hline \multicolumn{14}{|l|}{ Most important sources of information } \\
\hline My farm operator/lessee & $74 \%$ & $79 \%$ & $80 \%$ & $77 \%$ & $74 \%$ & $82 \%$ & $66 \%$ & $68 \%$ & $71 \%$ & $70 \%$ & $77 \%$ & $76 \%$ & $83 \%$ \\
\hline $\begin{array}{l}\text { USDA Natural Resource } \\
\text { Conservation Service }\end{array}$ & $63 \%$ & $54 \%$ & $67 \%$ & $54 \%$ & $48 \%$ & $58 \%$ & $62 \%$ & $49 \%$ & $52 \%$ & $62 \%$ & $53 \%$ & $63 \%$ & $59 \%$ \\
\hline \multicolumn{14}{|l|}{$\begin{array}{l}\text { Indicated interest in receiving information } \\
\text { and/or technical assistance }\end{array}$} \\
\hline Soil erosion control & $42 \%$ & $29 \%$ & $46 \%$ & $37 \%$ & $36 \%$ & $35 \%$ & $45 \%$ & $38 \%$ & $36 \%$ & $43 \%$ & $35 \%$ & $46 \%$ & $35 \%$ \\
\hline Soil fertility improvement & $50 \%$ & $44 \%$ & $41 \%$ & $37 \%$ & $41 \%$ & $39 \%$ & $47 \%$ & $37 \%$ & $40 \%$ & $43 \%$ & $37 \%$ & $46 \%$ & $38 \%$ \\
\hline Water quality improvement & $49 \%$ & $46 \%$ & $47 \%$ & $33 \%$ & $37 \%$ & $38 \%$ & $49 \%$ & $37 \%$ & $41 \%$ & $46 \%$ & $36 \%$ & $43 \%$ & $32 \%$ \\
\hline
\end{tabular}

Note: States are identified by postal codes.

the landlord (NOL) is not taking responsibility for conservation (Arbuckle 2019).

However, our results show it is much more complicated than landowners simply not wanting to implement conservation practices on their land. That is, conservation practices may be less likely on rented lands due to (1) renters' perceptions about landowner views, rather than truly knowing what those views are; (2) difficulties communicating with landowners who may live some distance away; and (3) the verbal and year-to-year nature of most leases, which makes conservation investment appear risky. In addition, AFT's experience working with NOLs shows they are often not aware of available conservation programs and are unsure about broaching the topic with their farmers, particularly if they lack on-farm knowledge and experience, which is particularly true for women NOLS (Petrzelka et al. 2018).

Thus, what this survey work suggests is that there is a communication gap rather than a difference in views between the landowner and renter, and that the gap is what has led to reluctance to implement conservation practices on rented land. This has been suggested in other recent research as well (Masuda, et al. 2021). Through targeted programming for farmers and landowners alike, including instruction on how to collaborate regarding conservation goals for the land, long-term leases, and implementation supported by government-funded conservation programs and joint investment, conservation outcomes can be improved nationally.

\section{IMPROVING NONOPERATOR LANDOWNER OUTREACH AND EDUCATION}

Targeted programming has already begun in Ohio and New York with a Great Lakes Protection Fund grant, with the goal of improving water quality in the Great Lakes. Two NOLs, Mary and Gina (sisters) grew up in the city of Rochester, New York. Summers were spent on the family farm. When their father passed, Mary and Gina each received a piece of the farm and with it, the responsibility of managing the land and its renters. When Gina received a postcard inviting her to a local Women's Learning Circle for farmland owners, hosted by AFT and Cornell Cooperative Extension, she was intrigued, signed up, and attended. "The first one was on soil conservation," Gina says. "That was an eye-opener for me."

After attending the Learning Circle, Gina set up an arrangement that incentivizes her renter to plant cover crops each fall with a $25 \%$ discount on his annual lease. "Gina is willing to share in the expense if we are going to do a good job of taking care of her land like we treat our own land," her renter states. Since attending the
Learning Circles, Gina and Mary talk to their renters several times throughout the year to keep informed on how the land is being managed, with an eye toward conservation and using soil health practices to improve drainage and other issues on their farm. "I think that was the biggest takeaway, that we can improve the soil," Gina says. "That we can make it better for the next generation, as opposed to getting our yield out of it now and moving on to let somebody else deal with it" (AFT 2020).

This quote, and our survey results, again suggest that a number of factors are more important to the NOLs in our study than financial considerations and that many of these factors revolve around conservation and farmland preservation. In fact, the findings show very clearly that NOLs are supportive of their renters taking conservation-oriented action on the land, and very willing to provide this support through changes in the lease.

Unfortunately, many leases across the country are only verbal, year-to-year leases. Therefore, there is an opportunity to provide more education among willing NOLs to take action to improve the terms of their leases and to increase the adoption of written leases, particularly with agreements that extend beyond one year, to improve the transparency between renters and landowners, and ideally enable both parties to take some short-term risks 
that should lead to long-term conservation benefits.

Some examples of efforts to improve communication and working with renters are seen in the work by AFT and The Nature Conservancy. Content on the AFT website (AFT n.d.) focuses on such topics as land assessments, leasing guides, educational events, connecting to the next generation of farmers, and managing the landlord/renter relationship. The Nature Conservancy website (The Nature Conservancy n.d.) also contains information that focuses on facilitating a productive conversation between farmers and landowners to reach conservation goals. Both organizations provide resources based on practitioner-led research and provide a gateway for connecting landowners and renters to technical assistance and general guidance for integrating more conservation on rented farmland.

\section{CONCLUSION}

The AFT survey and its results provide some of the most comprehensive information we have on NOLs across a diverse geography of landownership in the United States. The survey results help us to identify areas of future work that could lead those in the agricultural service provision, farmland preservation, and conservation arenas to focus their outreach efforts with NOLs to improve conservation outcomes on the landscape. The results also contrast with some research findings that NOLS are simply interested in getting their rent check for their farmland.

Greater action is needed to find, reach out to, and engage with NOLs, and ultimately, their renters, to help them access technical and financial resources that could help them improve the resilience of their lands. The survey data lay the foundation for future engagement and outreach with NOLs in order to achieve greater conservation adoption on rented lands.

\section{REFERENCES}

AFT (American Farmland Trust). n.d. Lease Your Land. https://farmlandinfo.org/lease-your-land/. AFT. 2020. Farmers and Landowners Partnering for Clean Water in the Great Lakes: Individual Stories from the Field. Washington, DC: AFT. https:// s30428.pcdn.co/wp-content/uploads/2020/06/
GINA-AND-MARY-GLPF-Stories-CoBranded.pdf.

Arbuckle, J.G. 2019. Iowa Farm and Rural Life Poll shows conservation increasing, but rented land remains a barrier. Iowa State University Extension News, July 2, 2019.

Bigelow, D., A. Borchers, and T. Hubbs. 2016. U.S. Farmland Ownership,Tenure, and Transfer.Economic Information Bulletin Number 161. Washington, DC: USDA Economic Research Service.

Green Lands Blue Waters. 2019. NOL Resources. https://greenlandsbluewaters.org/resources/nol/.

Land for Good. 2017. Conference Report: Changing Lands, Changing Hands. Keene, NH: Land for Good. https://landforgood.org/our-work/ changing-lands-changing-hands/report/.

Masuda,Y.J., S.C. Harden, P. Ranjan, C.B.Wardropper, C. Weigel, P.J. Ferraro, S.M.W. Reddy, and L.S. Prokopy. 2021. Rented farmland:A missing piece of the nutrient management puzzle in the Upper Mississippi River Basin? Journal of Soil and Water Conservation 76(1):5A-9A. https://doi. org/10.2489/jswc.2021.1109A.

Petrzelka, P., A. Sorensen, and J. Filipiak. 2018. Women agricultural landowners-Past time to put them "on the radar." Society \& Natural Resources 31(7):853-864.

The Nature Conservancy. n.d. A Healthy, Profitable Future Starts with a Conversation. https:// www.nature.org/en-us/what-we-do/our-priorities/provide-food-and-water-sustainably/ food-and-water-stories/farmers-landownersworking-together-conservation/.

Ulrich-Schad, J.D., N. Babin, Z. Ma, and L.S. Prokopy. 2016. Out-of-state, out of mind? Non-operating farmland owners and conservation decision making. Land Use Policy 54(July):602-13.

USDA NASS (National Agricultural Statistics Service). 2015. Farmland Ownership and Tenure. Results from the 2014 Tenure, Ownership and Transition of Agricultural Land Survey. Washington, DC: USDA NASS.

USDA NASS. 2019. 2017 Census of Agriculture. https://www.nass.usda.gov/Publications/ AgCensus/2017/index.php\#full_report. 